\title{
The Frontier: Economic Boom and Intellectual Bust'
}

By

James M. Youngdale

University of Minnesota

The frontier has been a matter of perennial concern for Americans, both scholars and nonscholars. This concern was revived in American Studies circles with the published works of Henry Nash Smith and Leo Marx, works which came to define a "myth and symbol" approach for understanding frontier and pastoral attitudes in American Life. In my view, this approch is inadequate in that it is wedded to a definition of culture as "the life of the mind." Rather, I prefer to think of culture in terms of a three level tier of reality which gives added dimensions to understanding the role of myths and symbols in society. Since my arguments dealing with the frontier and its images are based on methodological dissent, it may be helpful if I describe very briefly my own views on method as a prelude to a consideration of the frontier as a force in American culture.

It is convenient to think of a model for viewing culture in terms of three levels of reality. On the first level, there is the world of discrete objects which we perceive through our senses, the level stressed by Locke as the starting point for a theory of knowledge. At a second level, there are social groupings, formal and informal, which partly offer constituents a sense of identity and also a sense of power insofar as given social institutions operate as levers to create or resist social change. The third level of reality is that of ideological outlook or world view in a collective sense, always reflected in private lives. This third level is mostly expressed in intellectual shorthand with myths and symbols which in turn can be viewed as clusters or paradigms for understanding and evaluating all three levels of reality, which constitute culture in a total sense.

* This article is an amended form of a paper presented by Dr. Youngdale at the Convention of the American Studies Association held at San Antonio, Texas, November 6-8, 1975. 
While it is necessary to define the "factual" content of reality at each of the three levels with the help of quantification and other behaviorist tools, the larger challenge toward understanding culture lies in identifying the inter-relationships between reality levels $\mathrm{ONE}$, TWO and THREE in contrast with the customary emphasis on individual psychology at level one, on behaviorist social science at level two and on intellectual history or literary criticism at level three. There is not time in this paper to develop an adequate exposition of the problems in examining the interrelationships between the tliree levels; but let me suggest lor one matter that new theories of social psychology or psychohistory are needed to better understand these relationships. For example, I suggest that we build upon theories which stress a human striving for psychic consonance (homeostasis) as an axiomatic assumption, which helps explain the persistence of ritual as a reinforcement toward a sense of stability and continuity. Yet consonance is never easily achieved between the three levels of reality. Each level has its own history and rate of change, making for various kinds of social contradictions and conflict, both internalized and externalized, as persons chart their behavior and outlook in the social world in ways which often appear to be irrational to those who work with simplistic assumptions from hedonistic psychology or with a Freudian unconcern for the complexity of cultural change.

In a positive vein, I find it helpful to juxtapose the psychology of Alfred Adler with the notion of history as a succession of world views or paradigms, to use a term popularized by Thomas Kuhn in his The Structure of Scientific Revolutions. Furthermore, it is helpful in the social world to think $\mathbf{s}$ pa adigms as overlapping in time, making for a necessity that we are all caught in a world of conflicting views of reality and hence that we must make choices. On both an individual and a collective level, choosing is always a difficult mattei, making most often for ambiguity and vacillation rather than for a clear-cut commitment to some certain ideological outlook. In the context of this paper, I a m concerned with the significance of the frontier as a part of American world views, first under the classical liberal paradigm and then under progressivism and with ambiguities which developed as a paradigm revolution developed in moving from the nineteenth to the twentieth centuries.

Let me use an example which illustrates this abstract description of my model and which at the same time leads into an examination of the frontier as a factor in our history. Let us think of the cowboy 
at the third level of reality as a multisymbol for freedom, machismo, undemocratic resolution of conflict (with guns) and other variations of these attributes, especially as romanticized in popular culture. However, at levels one and two, the cowboy was often a lonely, unhappy individual, employed for wages by a large cattle company and furthermore, the cattle companies usually prohibited cowboys even from carrying guns since shooting spooked cattle and caused costly stampedes. It is clear that there is a contradiction between the cowboy as a symbol and the facts of his existence within the social institutions of his time. If cowboy symbolism does not explain "real" cowboys, what, then, is the function of this symbolism in view of its popularity in American culture generally? This is the question to which this paper is addressed, looking not just at cowboy symbolism but more generally at the frontier as a source of pastoral images which contribute to a larger cluster of myths in American history.

The concept of the frontier has achieved a special and important place in our metaphorical baggage. It has been employed with reference to nineteenth century experience to represent untamed wildness and, in some contradiction, the agrarian West somewhat tamed by yeoman farmers or cattle companies. In a larger view, the frontier has acquired a number of connotations, such as unrestrained freedom, growth arid expansion, idealized democracy, pastoral bliss and primitive innocence, all of which imply wholesome and morally acceptable values in existence or desired. These values attached to the frontier are represented by various images, such as the West, the rural country, the hunter, the yeoman farmer, the cowboy or open space, all as counter images to the East, the city, Europe or the complex network of civilized institutions in modern society. Parenthetically, I wish to observe that there is opposing symbolism sometimes associated with ruralism, namely, values stressing a sense of a caring community often around a parish church or a school or stressing a populist interest in cooperative or communitarian political tactics; however, I feel that these tendencies have been subordinate in our culture to the more important emphasis upon rugged and free individualism, often symbolized with agrarian images.

In looking more directly at frontier or pastoral symbolism and its relation to the other two levels of reality, it is understandable that this kind of symbolism has sunk deep roots in American culture. Too few scholars have pointed to the particular conjunction between 
frontier mythology and laissez-faire capitalism of the nineteenth century. Too few have suspected that the frontier, through its role as a stimulus to economic investment, served to prolong the era of petty capitalism. By this token, it contributed toward deeply imbedding classical liberal theory and values, celebrating the selfreliant, autonomous man while denying conceptually the existence of the institutional level of reality, making for so-called American innocence, more properly ignorance of the social roots of culture. This kind of ignorance was serious enough in the nineteenth century when the fact of the frontier made for economic expansion and growing prosperity, leaving the illusion that Adam Smith's "invisible hand" tunctioned to create social harmony; but this ignorance is a disaster in the twentieth century as a form of social amnesia in a complex world of institutions. Let me enlarge upon the argument of this paragraph.

In spite of the assumption in classical liberal ideology of atomistic man outside of group and institutional forces, there were in retrospect many kinds of such forces which served as carriers of culture and as vehicles for indoctrination. There were the public school system, churches, trade unions, business associations and other kinds of mass movements; and in addition, there was the frontier with its new immigrants as a special force and as a "fact" on all levels of reality. With the arrival of millions of new immigrants on the moving frontier in the nineteenth century, some invested in farming but all became industrial consumers who helped clear the market of a plethora of goods and services. This condition made for a fairly continuous economic boom in the United States economy. The expectation of an expanding market meant that it was possible for new industries to move westward, always adopting the newest technology with unskilled labor involved in mas production techniques which were rationalized by Frederick Winslow Taylor.

It was under these circumstances that American optimism emerged as a "barbaric yawp" (Walt Whitman) and that frontier symbolism also evolved, not as a description of frontier "reality" but rather as a poetic celebration of the frontier for its role as an economic "pump primer." The frontier was an investment outlet which averted a serious oversavings crisis; and this fact meant that the illusion was ingrained and prolonged in United States culture that Adam Smith's invisible hand was operative and that governmental intervention or social planning in economic affairs was anathema and a violation of "freedom." The observations of this paragraph 
were reflected, I think, in a painting by George C. Bingham, who portrayed Daniel Boone leading settlers into the promised land with Boone dressed, not in a coonskin cap, but in neat buckskins cut in the style of a business suit. Here we see Boone as the agent for a land company, undoubtedly hoping to "strike it rich" through speculation in land at a railroad or canal terminus. In Boone, we have two levels of reality, the mythic hunter in a coonskin cap and the "other" man as a speculator-investor. The two levels are linked under a larger transcendental unity around the concept of freedom as a higher ideal.

It is possible to detect the frontier (pastoral, green, west, rural) dream far back into history, often as implicit protest against authority and constraints imposed by industrial civilization, as Leo Marx has done in The Machine in the Garden. This dream developed a special force and meaning in American experience with the rise of high culture transcendentalism coincidental with the flowering of petty capitalism as a counterpart to popular culture pastoralism. It was at this time that a neo-pantheism emerged, equating God with nature. It was at this time that Nature became a spiritual force both as a source of affirmative moral values and as a redemptive power in which evil and death are dissolved. (Walt Whitman: "Look for me under your bootsoles.")

The transcendental imagination attempted to fuse the Lockean theory of knowledge originating in sensations of discrete entities with Platonic idealism, the latter expressed with symbols of Nature. (Ralph Waldo Emerson: "In the woods, too, a man casts off his years, as the snake his slough, and at whatever period in life is always a child. In the woods is perpetual youth... I become a transparent eyeball; I am nothing; I see all; the currents of the Universal Being circulate through me; I am part and parcel of God.") This imagination is consistent with the classical liberal paradigm which conceived of discrete, autonomous man linked to spiritual realities and joined in community only at the "oversoul level," which precluded viewing man in the midst of human history or social institutions. Thus, in the nineteenth century there was no discipline of economics or sociology, only that of moral philosophy as the formal basis for liberal arts education. It was a short step from adapting a philosophic commitment to Nature as a spiritual force to the various images of the frontier, expressed variously as wildness, the yeoman farmer or the "new man" without a history as symbolic images arrayed against the East, Europe, the city or other mani- 
festations of institutionalized civilization. Normally, the concept of the noble savage would be included in such a catalogue of values related to pastoralism; however, in America, the savage was more than an abstract concept representing innate goodness in human nature. Here, they were flesh and blood people, who had been tolerated as long as they trapped beaver but who became the ignoble savage as the fur frontier was replaced by the wave of farmer settlers coveting Indian land.

As the era of petty capitalism was transformed into corporate capitalism, it was difficult to hold to the easy optimism implicit in the utopian vision of Adam Smith and tolerant, classical liberals, At a concrete level, the spiritual symbols of beneficent Nature were contradicted by a perception of violence, hate, poverty, panics, and other social phenomena which seemed to negate the image of America as a Garden of Eden. Those who saw and wrote about this contradiction we categorize as literary naturalists. For those writing in this vein, Nature was still a source of symbolism but now as an environmental force with fatalistic implications for suffering and evil. This tragic outlook was formalized by Zola in Germinal and was explicit in the writing of Mark Twain, Frank Norris, Jack London and Hamlin Garland, to name just a few American naturalists. Those writers having some contact with those western regions which were considered part of the frontier were all disillusioned with the impact of the frontier or the prairie on the lives of people, none more poignantly than O. E. Rolvaag, who entitled the last chapter of Giants in the Earth, "The Great Plain Drinks the Blood of Christian Men and Is Satisfied."

While the naturalist writers are noted for their "realism" or "veritism," almost to a person they fall back upon the transcendental notion of Nature as a redemptive force as their basis for an affirmative outlook, making for the "divided stream" Charles Walcutt has observed. ${ }^{1}$ Almost without exception, naturalist novels. on the last page or even the last paragraph find spiritual meaning in grass, wheat or the west or in some other frontier/pastoral symbol. Nature is a deus ex machina, an intellectual and emotional escape route, dramatized in one last sentence by Huck Finn guessing he'll head for the territories.

The naturalist genre has persisted into the twentieth century in Sinclair Lewis, Ernest Hemingway and others. In Min Street, Lewis. finds much to criticize; yet finally, Carol Kennicott returns to the "clean, fresh air" of Gopher Prairie as the suitable place in which 
her son might grow to maturity. In the end, Lewis' radicalism was only skin deep. Sometime ago, I asked a 90-year-old friend, who was a boyhood playmate and friend of Lewis, about Lewis' views in a positive sense. "Oh," he said, "Red [Lewis] didn't know where he was at. All he could do was bitch." Perhaps, this is an appropriate epitaph for the naturalists: "All they could do was bitch"; yet I argue they at bottom did believe in the transcendental dream of unrestrained freedom for autonomous man as a commitment to the classical liberal or laissez-faire paradigm. It is no surprise, then, that many of these writers came to celebrate the tough, self-sufficient, imperial, autonomous male as hero. It is understandable that many in their private political lives gravitated to the far right on the political spectrum, including such persons as Steinbeck, Dos Passos and Garland, even though some may have been considered "radical" or even "proletarian writers" in earlier periods. In these persons, apparent "radicalism" was essentially a nostalgia for agrarian capitalism as they protested against the evils of urbanism and industrialism.

A nostalgia for agrarian capitalism in idealized form has been ever present in the thought of many political activists whom we label as populists who have waved the banner of anti-monopolism. These, too, have shown tendencies toward becoming political reactionaries, as Richard Hofstadter has argued in The Age of Reform; however, Hofstadter failed to note counter currents in populist movements which have stressed the need for structural reform with influences from such socialists as Eugene Debs and Victor Berger. Even many Marxists, whom one might expect to reject both the agrarian and the industrial versions of capitalism, have celebrated, at times, cultural currents from the petty capitalist era, Walt Whitman as a case in point. ${ }^{2}$ In my view, Whitman, like other transcendentalists, leaped back and forth from empirical description to Platonic idealism, ignoring in naive innocence the level two factors concerned with man in an institutional and historical setting. As dream and sordid reality seemed to diverge for Whitman after the Civil War, he could only express disillusionment and rage, serving as a prototype for the Beat generation following World War Two.

The new realism which found expression in literary naturalism was evident among the social scientists as well, giving rise to the very concept of social science. Frontier symbolism was employed most directly by historian FrederickJackson Turner, one of the last of the 
transcendental innocents, who linked a theory of geographical determinism with the myth that Nature and democracy are directly linked. Other progressives abandoned Turner's simplistic geographical determinism for theories based on social determinism, which at least admitted the existence of social institutions. However, like the literary naturalists, the social scientists of the early progressive era mostly wished to negate or evade the institutional complexity they observed in favor of a simpler society in which "good" primitive human nature would prevail, an analysis which has been developed by David Noble in Historians Against History. ${ }^{3}$

Political progressivism as symbolized in the presidencies of Woodrow Wilson, Franklin Roosevelt and John Kennedy, even while espousing limited reformism, has been markedly committed to expanding capitalistic investment in a "free world." While some of these progressives, such as Franklin Roosevelt and Henry A. Wallace, have advocated a benign and peaceful form of noncolonial, marketplace imperialism, the fruit of this mentality was finally the disastrous intervention in Vietnam initiated significantly under President Kennedy's "New Frontier" slogan. The parallel between the new world frontier and the old frontier of the United States West is striking in that both incorporated the notion of the investment safety-valve to alleviate tendencies toward oversaving and disequilibrium in the capitalistic part of the world. Both frontiers have been justified with traditional mythic forms, such as the purge of social forces too primitive to join the modern world while employing the rhetoric of petty capitalist idealism associated with the yeoman farmer. Thus, there has been the "good Indian is a dead Indian" slogan of the American West and the body counts in the Vietnam frontier, all in the name of transcendental idealism expressed as freedom and liberty so much celebrated in the pastoral West.

Part and parcel of the progressive revolution at the turn of the century was the rise of pragmatism as a philosophical outlook which attempted to fuse tender-minded romanticism with tough-minded materialism in the terminology of William James. The pragmatists aimed to understand the import of transcendental abstractions by reducing them to practical effects in everyday life, by looking beyond words at deeds. At the same time, they altered the Lockean side of the transcendental stream, notably in James' theory of radical empiricism while they still focused on the discrete and the ideosyncratic in support of pluralism and variety as positive values. 
They failed to come to grips with the social nature of man's existence with their stress upon a relativity of truth based on individual and not socially shared conceptual frameworks, especially in the case of William James and other early pragmatists. Exceptions were Thorstein Veblen and Carl Becker who wrote respectively of "habits of thought" and the "climate of opinion" as institutional forces. Yet even these two men were pessimistic over any collective resolution of institutional malfunctioning, Veblen seeing hope only in primitive goodness (instinct of workmanship) and Becker retreating to extreme pragmatic relativism in the form of "every man his own historian." Thus, this side of pragmatism was that of restating and reinforcing the liberal individualism of the laissez-faire era as was also the case with most literary naturalists and social science progressives. It has been easy to dramatize pra matic doctrine with frontier images, for example, with the yeoman farmer as a "doer" who improvised and invented to meet the exigencies of his situation or more generally as good American "get up and go." From Rolvaag's Giants in the Earth, Per Hansa comes to mind as a type much honored as "the backbone of America," so to speak, the practical achiever without an overt commitment to any grand theory or scheme of things.

The persistence of frontier mythology as an intellectual force in American life has been a source of tragedy in America. In personal lives, frontier mythology linked with petty capitalism has raised an impossible dream of moral perfectionism and private omnipotence as aspirations. Chasing the rainbow of exaggerated aspirations means that most individuals are condemned to failure or to a modern sense of sin as a wide gap develops between their dreams and everyday reality. So, in spite of the much touted American success myth connected with the Dream, America can moge properly be understood as the Land of Psychic Failure, with the exception of an occasional "moral athlete" here and there. Response to failure varies; let me note a few of the variations. Some people retreat into apathy, despair or nihilism. Some seek to enjoy omnipotence vicariously, perhaps in identifying with the United States army clobbering a peasant society in Vietnam. Some vent their anger privately, against husbands, wives and children; and others display racist or sexist anger toward minorities, perhaps to reinforce a shaky sense of superiority. I have described these responses in other writing under the rubric of "the pathology of perfectionism." Richard Slotkin has looked in more detail at these kinds of responses 
by those who view the world through pastoral lenses in Regeneration Through Violence: The Mythology of the American Frontier, 1600$1860 .^{4}$

There have been those failures who reject dominant American values and who seek a new form of consciousness, often with tinges of Asian mysticism. There have been the Beat poets, Charles Reich's The Greening of America, and more recently Robert Pirsig's Zen and the Art of Motorcycle Maintenance, all of which tend toward a private existentialism as an escape from social responsibility. Paradoxically, this kind of privatism is little more than an updated version of transcendental idealism and a continued American innocence of man shaped by and shaping social institutions. For these new idealists, the stage is set for future disillusionment and then again new responses. Even now, it is possible to observe that these types of counterculture people, when they do become politicized, attach themselves to the far right of the political spectrum, for example, the movement for unification led by a Korean Christian, Rev. Sun Moon, who has defended Richard Nixon to the bitter end.

Not all Americans have been so committed to the American Dream that they have been unable to perceive a tragic element in American life as the gap between dream and reality has widened. An excellent study, The Closed Frontier : Studies in American Literary Tragedy, by Harold $P$. Simonson explores exactly this form of tragedy. Simonson examines in detail the works of Mark Twain, Ole Rolvaag and Nathanael West as writers who perceived the problem of believing in the frontier dream and in trying to act upon it. I should like to make a few observations of my own as footnotes to Simonson's study.

In Giants in the Earth, Rolvaag has counterposed Per Hansa's quest for the American Dream embodied in the yeoman farmer with Beret's nostalgia for old world community and security as represented by the Norwegian fishing village from which the couple had emigrated. Rolvaag, through the voice of an itinerant minister, complains of "that loneliness which some Americans call freedom," an observation which prefigures Erich Fromm's argument in Escape from Freedom that competitiveness and loneliness are preconditions for personal and collective madness.

While Rolvaag's affirmative values seem to be reflected in his sympathy for Beret and her bereavement over leaving Norway, this attitude also speaks for a commitment to old world culture and a sense of rootedness in community, which the itinerant minister 
illustrates with his "Parable of the Rope" in a sermon which had a healing effect upon Beret. It was a story of an immigrant mother with eleven children arriving in chaotic New York. This mother tied a rope around her waist and then around the waists of each of her children so that none should be lost, the rope serving as a symbol of a caring community which was so lacking for Beret on the South Dakota prairie in company with her ambition-ridden husband, who, like Melville's Ahab, seemed to defy the forces of Nature and God in his monomania for founding a kingdom for himself on the American prairie.

In Giants in the Earth, Beret indeed does become mad; however, it is well to raise the question as to whether Per Hansa's egomania was not also a form of madness from the very first as he pushed into the desolate prairie without giving Beret a chance to communicate her sense of foreboding. Even though prodded by Beret, Per Hansa did finally commit an act of suicidal madness in setting off on skis in a blinding blizzard, feeling defeated after his realization that Beret's madness had been partly his responsibility for having insisted they come to America before she was ready to leave. In the end, Rölvaag was apparently ambivalent; for Per Hansa's body was found by a haystack facing west, still the direction in which lay the American Dream. But again, Harold Simonson quotes the other side of Rolvaag's ambivalence. "It's nothing but a common, ordinary, romantic lie that we are 'the captains of our souls'! Nothing but one of those damned phrases. Just look back over your own life and see how much you have captained! Your have been nothing but an ordinary hand on the fo'castle. And that is all we all are." ${ }_{5}$

In The Great Gatsby, F. Scott Fitzgerald gives frontier symbolism an ironic twist in transporting James Gatz from North Dakota (West to East) and giving him new birth as Jay Gatsby, a New York bootlegger in the big time. In this novel, the major symbol of Nature is the "green" light on Daisy's dock (an unnatural symbol of Nature). Yet Fitzgerald, too, seems ambivalent; for finally, Nick Carraway is attracted to Gatsby for his dream of a transcendental ideal as represented by beauty in Daisy. In the end, Carraway, after wondering what Long Island was like in those pristine days when Dutch sailors first arrived, packs his bags and heads back to the midwest, leaving the careless and irresponsible people of "the East" behind him, just as Sinclair Lewis' Carol Kennicott returned to Gopher Prairie after discovering that "the East" was simply Gopher Prairie writ large. Yet, Fitzgerald seems to suggest that the "green" 
dream is a sham and an illusion as he wonders in the last sentence if we are condemned to futilely row against the current toward a receding speck of green on the horizon, a line which suggests that Carraway's return to the midwest was a final bit of irony. There is ambiguity and confusion in Fitzgerald, however; for in expressing outrage through Carraway with the social irresponsibility of the people in "the East," he uses "the West" as a counterpoint when contrarily "the West" has served as the very symbol for the rugged and insensitive individualism which Fitzgerald observes in a decadent upper class setting on Long Island. ${ }^{6}$ Fitzgerald's failure lies in being unable to define an alternative to "the West" as a symbol for the kind of social responsibility for which he yearns.

Perhaps, the most explicit statement rejecting American frontier mythology comes from the pen of D. H. Lawrence, who, as a foreign observer, saw American culture from a fresh point of view. "Men are free when they are living in a homeland, not when they are straying and breaking away. Men are free when they are obeying some deep, inward voice of religious belief, obeying from within. Men are free when they belong to a believing community actively fulfilling some unfulfilled, perhaps unrealized purpose, not when they are escaping to some wild West, and shout freedom... The shout is a rattling of chains, always was."' While I might wish to disagree with Lawrence's statement with the suggestion that freedom implies a conscious realization of purpose; nevertheless, this assertion stands as an indictment of the mainstream of American culture which has been so steeped in the ideology of individualistic petty capitalism expressed mostly as frontier mythology. For all of his bombast against the empty idealism and the stuffy, smug arrogance of such persons as Benjamin Franklin and Walt Whitman, Lawrence in his own way is an innocent who is unable to furnish a prescription for America other than to suggest "getting down to the deepest self," existentialism. This is roughly the identical, limited prescription offered by Hawthorne who urged that we purify the heart and "the many shapes of evil that haunt the outward and which now seem almost our only realities, will turn to shadowy phantoms, and vanish of their own accord." 9

Perceiving tragedy (or sin) as a failure to approximate aspirations is one matter; diagnosing the problem and finding a prescription is another. It will not do to retreat into some form of private innocence which may permit temporary relief from the tensions of life for a 
few; but for the many, life furnishes mostly unhappy experiences, such as marching off to war, being unemployed, paying a heavy tax burden with little perceived benefit in return and more. There is a need to restructure our mainstream, not just in forms of consciousness but also in altering or inventing new social institutions. Yet, paradoxically, we can only alter institutions if we develop a new consciousness which provides a mental map for reform; and so we return to the question of world view or paradigm.

In the course of paradigm revolutions, it is common that old symbolism is transvalued toward new understandings of a changed reality. In the twentieth century, the pioneering concept has shifted in meaning from geographical settlement to social innovation, most notably in the case of President Kennedy's call for a "new frontier" which became the slogan for his administration. Kennedy's social idealism was soon subverted by his own decisions as the new frontier became a military frontier in Vietnam, a reversion to geographical pioneering. We need to more fully understand the crisis of our time as one in which the investment frontier has degenerated largely into a permanent war economy in contrast with the nineteenth century when at least there was positive construction of railroads, farms and industries in a fairly peaceful century, peaceful if we conveniently ignore Indian and slave revolts.

On the level of popular culture, I suspect that there is currently a renaissance of nineteenth century values around frontier symbolism among vast numbers of people across the entire class spectrum who are distressed with the malfunctioning of big government and big corporate bureaucracies, and who yearn for the simple, selfreliant life of a lost rural paradise. Like the literary naturalists, these people often express their discontents in anarchistic and iconoclastic rhetoric; yet their commitment to the futile dream of old-fashioned individualism clothed in frontier symbolism precludes an imagination for dealing creatively with restructuring and democratizing the institutions in which our lives are intertwined. It seems predictable that these types of people, as their frustrations mount in their futile nostalgia, will exhibit ever more negative protest, mindless violence (viewed as crime) and even aimless "revolution for the hell of it" to quote Abbie Hoffman, an erstwhile young radical. Politically, these tendencies seem destined to bolster the anti-Establishment forces on the right along with the pseudo-populist leaders who often satisfy yearnings for stability and psychic security with country music styles celebrating "old time religion" and simplistic economic panaceas. 
The persistence of frontier and pastoral symbolism in both high and popular life in America raises the question as to whether we should try to totally abandon frontier mythology or to transvalue it even more fully than simply to proclaim an aspiration for a "new frontier" in a vague social sense. In any event, frontier mythology must be understood in its finer details, especially its burden of perfectionism and omnipotence which leads so easily into pathology. It is time to understand that omnipotent or rugged individualism is the antithesis of democracy and rather that living in a democratic community implies a process of give and take or mutual compromise in which perfection is not possible. This same point has been made by Harold Simonson in other words. "When a nation, like a person, comes of age, it recognized that limitation is a fundamental fact of life. Painfully, it admits that possibilities can only be finite and progress only limited, that solutions to problems are found more often through compromises than crusades. It discards illusions about national invincibility and divine right to exercise power. It also abandons the dream that a second chance mollifies responsibilities here and now. Coming of age means awakening to the tragic realities that nations, like men are mortal; that truth comes chiefly through ambiguity and paradox; and that the old inheritance of pride carries its inexorable consequences." 10

It is not enough to call for populist proposals at a concrete level. America needs a new paradigm revolution, a new symbolism celebrating community, social purpose and democratic planning. Without a new world view, it is doubtful if even pragmatic reforms will be adopted to a meaningful extent. For example, I doubt if American cities can become viable until there is a sufficient "socialistic" consciousness to nationalize land ownership in and near cities to neutralize the power of real estate interests in city planning, as was the case in the Stockholm area where much land on which suburbs were built had been held by the crown.

It is not enough to join with literary critics in noting irony and in deploring tragedy inherent in American culture for its commitment to frontier and pastoral myths, even though some critics do this very well at a myth and symbol level. Critics have been facile in cursing the darkness while failing to light a candle to indicate practical steps in the social and political arena for ending the dissonance they sense. Leo Marx's Machine in the Garden is a case in point of a study in which the final sentence notes that "the machine's sudden entrance into the garden presents a problem that ultimately belongs 
not to art but to politics."11 (Emphasis mine). One can wonder why Marx has failed to interweave a political perspective throughout the book, not as an afterthought in the last sentence, an afterthought which seems to vitiate his study. Nevertheless, this last sentence does reflect a plaintive wish for an organic concept of society with a new fusion of art, politics and economics. In suggesting a vision for institutional reforms based on a concept of society as a living organism, let me deplore the fact that in the past those who uphold organicism and tradition have often been viewed as conservatives or even reactionaries. Under the banner of organicism, traditions and institutions can be changed in reformist or radical ways, still with the stress expressed by D. H. Lawrence that we are free in a believing community, not shouting freedom in some wild West.

I do not wish to denigrate efforts to define practical programatic solutions to pressing current issues. New programs and new institutions will be needed, which might be perceived as being socialistic or populistic in intent. I suppose that I could elaborate upon my ten favorite populist reforms for social reform. These kinds of ideas are easy to generate, whether nationalizing railroads, expanding education, reforming the tax structure or financing public works for full employment as minimal kinds of restructuring; however, I submit that writing populist manifestos can be only an exercise in futility as long as the predominate currents in American intellectual culture are defined in terms of frontier mythology, whether as cowboy individualism or private back-to-nature cultism. There is a pragmatic side to American political culture which supposes that reforms are simply technical matters, that all we need is a more efficient welfare state and that we are at the "end of ideology." Nothing could be further from the truth. There is always ideology; and those academicians who prattle about the end of ideology are in most cases themselves committed to frontier mythology in some form, notably to the sense of national omnipotence which was used to rationalize United States' presence in Vietnam. The end-ofideology intellectuals are simply evading the proposition that frontier mythology is bankrupt, an "intellectual bust" to use the title of this paper, and that it prevails as a cultural lag long after the frontier stopped serving as an economic pump-primer through new investment opportunities.

There is no simple formula for achieving new forms of social consciousness with new symbolism. Small beginnings might be found in Rolvaag's parable of the rope and in Puritan John Winth- 
rop's "Model for Christian Charity," reflecting a positive commitment that we. are all tied together in a world of institutions which we may wish to reshape, not flee from, if we would bring a sense of order and harmony to the modern world. Finally, I would suggest that America's form of "future shock" will not be one of confronting technological innovations (we do this with exuberance), but rather one of confronting new ideas without undue trauma. In the 1960s, many middle American., were traumatized by young people's long hair, which was then a symbol of counterculture ideas. If hair is such a problem, can we do better in formally dealing with ideas as such? To end this paper with this question is to end on a pessimistic note, but hopefully, raising the question is itself a step toward a new consciousness and thus toward a new sense of optimism.

\section{NOTES}

1 Reference here is to Charles Walcutt's American Literary Naturalism = A Divided Stream (Minneapolis : University of Minnesota Press, 1956).

2 See, for example: Samuel Sillen Walt Whitman : Poet of American Democracy (New York: International, 1944).

3 Full citation: David Noble Historians Against History (Minneapolis: University of Minnesota Press, 1965).

4 Full citation: Richard Slotkin Regeneration Through Violence: The Mythology of the Frontier, 1600-1860 (Middletown: Wesleyan Press, 1973).

5 Harold P. Simonson The Closed Frontier: Studies in American Literary Tragedy New York: Holt, Rinehart and Winston, 1970) p. 87.

6 Leo Marx The Machine in the Garden (New York: Oxford, 1974) See the last chapter, "Epilogue: The Garden of Ashes", for further discussion of meaning in The Great Gatsby.

7 D. H. Lawrence Studies in Classic American Literature (New York: Viking, 1968) p. 6.

8 Ibid.

9 Op. Cit. Simonson. The Hawthorne quotation is from "Earth's Holocaust."

10 Ibid. pp. 5-6.

11 Op. Cit. Leo Marx, p. 365. 